\title{
Stravinsky, Hogarth and Bedlam
}

\author{
P. Crichton
}

“Hogarth's Rakes's Progress paintings, which I saw in 1947 on a chance visit to the Chicago Art Institute, immediately suggested a series of operatic scenes to me." (Stravinsky \& Craft, 1960). By 1947 Stravinsky's career, which had started so brilliantly and stormily with the revolutionary Rite of Spring, was almost totally becalmed. Since emigrating from Paris to California in 1940, he had written a couple of untempestuous orchestral pieces, Circus Polka. "composed for a young elephant", and little else. He was depressed by the lack of originality of his work and was eager to write an opera in English. When he saw the paintings of the Rake's Progress, he seized his opportunity.

Stravinsky wrote to his liberettist, the poet W. H. Auden, "As the end of any work is of importance, I think that the hero's end in an asylum scratching a fiddle would make a meritorious conclusion to his stormy life. Don't you think so? Auden immediately agreed: "I think the Asylum finale sounds excellent." Stravinsky replied a few days later by telegram: ". . . . All things considered, find impossible discuss this important matter by letters. Could you spend few days my home? Gladly take care your airline expenses." Auden responded the following day: "Many thanks for wire and generous offer shamefacedly accepted . . ." (Stravinsky, 1982).

Auden arrived on 11 November 1947 at the Stravinskys' Hollywood home, just off Sunset Boulevard. "Early the next morning, primed by coffee and whisky, we began work on the Rake's Progress. Starting with a hero, a heroine, and a villain, and deciding that these people should be a tenor, a soprano. and a bass, we proceeded to invent a series of scenes leading up to the final scene in Bedlam that was already fixed in our minds. We followed Hogarth closely at first and until our own story began to assume a different significance." (Stravinsky \& Craft, 1960) In ten days they had reconstructed Hogarth's plot, completed a synopsis, and drafted fragments of dialogue and a plan for musical pieces within the scenes (Carpenter, 1981),

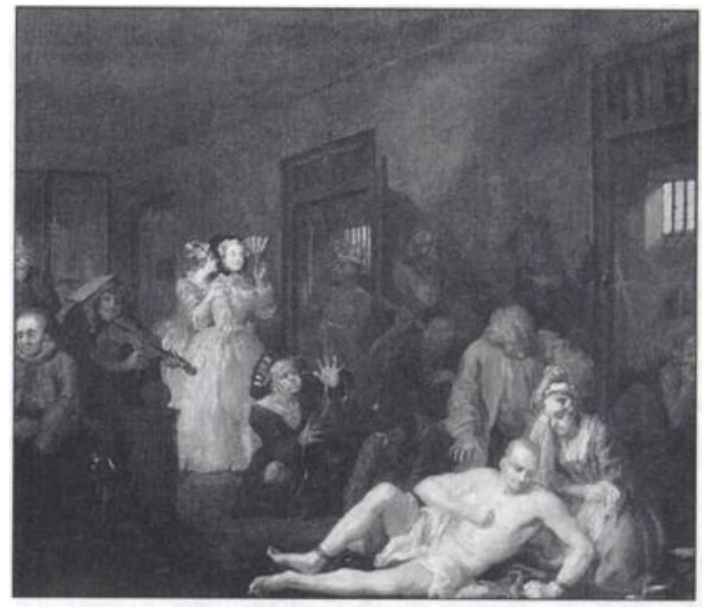

Figure 1. 'The Madhouse' from Hogarth's 'A Rake's Progress'. By courtesy of the Trustees of Sir John Soane's Museum.

although it required three years to finish what was to be Stravinsky's only full-scale opera and his longest single work. Later, Auden recruited his friend, Chester Kallman, as coauthor. The result of this collaboration is one of the finest libretti ever written.

It is clear from this correspondence that Stravinsky's initial ideas for the opera were very sketchy. The germ of the opera seems to have been the final scene in Bedlam. In Hogarth's painting of this scene there is a figure on the left wearing a score on his head and playing a one-stringed fiddle. According to Auden (1968), this figure was what triggered the Idea of the opera in Stravinsky's mind. Auden felt that of the scenes depicted by Hogarth only two, the brothel and the madhouse, were operatic in character. He also believed that "in order to sing, all characters have to be a little mad" (Carpenter, 1981). Vera Stravinsky also drew attention to the significance of the Bedlam scene in the opera in her description of the world premiere in the Teatro La Fenice in Venice on 11 September 1951: "But it seems to 
me that Igor has saved the finest moments of all for the final scene. These are the music of 'Venus, mount thy throne,' the duet 'In a foolish dream', and-the most touching music Igor ever wrote-Tom's 'Where art thou, Venus?' ".

Auden (1968) felt that Hogarth's Rakewell was too passive for an opera. He and Stravinsky decided to split him into two characters, Tom Rakewell and his Mephistophelean companion, Nick Shadow, who, as in Goethe's Faust, satisfies the whims of the hero in return for his soul. They also intended in this way to externalise Tom's inner conflict by manifesting on stage the tempted and the tempter. After leading the life of a libertine for a year, Tom meets Shadow in a churchyard. They play cards, Shadow loses and sinks into the grave. With his last words he puts a curse on Tom:

To reason blind shall be your mind

Henceforth be you insane!

Thus Stravinsky and Auden fused, not altogether satisfactorily, two very disparate stories into their opera: Hogarth's Rake's Progress (the Heir, the Levee, The Orgy, The Arrest, The Marriage, The Gaming House, the Prison. The Madhouse) and the Pact with the Devil. The graveyard scene could well have concluded the opera. It is not entirely clear why Shadow should put a curse of madness on Tom, except that this then leads into the asylum scene which was so important to Stravinsky.

What was it that drew Stravinsky to the Bedlam scene? Certainly Hogarth's painting is arresting. Tom is lying in the foreground, shackled and virtually naked. There is an open wound on his left chest, possibly selfinflicted. His posture is reminiscent of the two famous statues of Raving Madness and Melancholy Madness by the German sculptor, Caius Gabriel Cibber, but also of Renaissance paintings of Christ's deposition from the Cross. Cibber's famous statues were originally placed at the entrance gates to the Bethlem Hospital ('Bedlam') in Moorfields and can now be seen in the Museum of the Bethlem Royal Hospital in Beckenham. Alexander Pope (1943) in his Dunciad calls these statues "Great Cibber's brazen brainless brothers." Behind Tom kneels his faithful love, Sarah, while the man beside her tries to avert her gaze. To their right the inmate of a cell reclines on a bed of straw and stares in ecstasy with clasped hands at a cross. In the next cell stands a naked man wearing a crown and holding a stick as a sceptre. Behind the cell door a man is drawing on the wall. Two fashionably dressed ladies visiting Bedlam look on with amusement, one coyly hiding her face behind her fan, the other whispering in her friend's ear. In the middle of the painting a small figure sits cross-legged like a tailor and twists what looks like a measuring tape around his hands. The posture of his right hand, with the thumb hidden from view, appears dystonic. Next to him is a man, possibly blind, but holding a rolled paper like a telescope to 'examine' the ceiling. On the left of the painting sits a man staring disconsolately into space; behind him a man wearing a conical paper hat decorated with crosses, holding a triple wooden cross and chanting; and to his right the blind musician with the score on his head and playing a broken violin. On the wall between the two open cells is a medallion depicting Britannia with hair awry, as if to suggest that the whole country had gone mad.

'Mad scenes' are a favourite device of operatic composers. The temptation to exploit the perceived dramatic effect of disturbed behaviour and thinking on the stage seems to be very difficult to resist.

Over the ages various hypotheses about what causes madness have been proposed. These include:

(a) love (the 'Crazy-for-You hypothesis')

(b) possession by spirits or the Devil (the 'Exorcist's hypothesis')

(c) toxic substances, e.g. alcohol, mercury, etc. ('the Mad-Hatter hypothesis')

(d) artistic creativity or possession by the Muses (the 'mad-genius' hypothesis)

(e) heredity factors (the 'Philip-Larkin hypothesis')

(f) psychological stress (the 'Shell-Shock hypothesis')

(g) physical illness (the 'neurocidal-virus hypothesis')

The libretto explicitly states that Tom's madness is the result of Shadow's curse, his revenge on Tom for losing the game of cards and thus his life. In this sense the explanation is religious and is in accordance with Auden's remark (1968) that the libretto was a mixture of fairy story and medieval morality play. Tom, however, is not being punished for his life of self-indulgence; in fact, his soul, though not his sanity, has been saved by the intervention of Anne, who still loves him. But there are 
resonances of other possible aetiologies in the opera: perhaps Tom contracted syphilis at the brothel, as the pathetic husband in Hogarth's Marriage à la Mode does, and later developed General Paralysis of the Insane; perhaps the stress of losing his fortune twice and ending up in the debtors' prison pushed him over the edge.

In his first letter to Auden, Stravinsky (1982) makes the interesting error of misidentifying the hero with the mad musician in Bedlam. Stravinsky may have been reminded of his own composition The Soldier's Tale in which the violin is a central image for the Soldier's soul and may thus have been drawn to Mephistophelean theme which was added to the 'moral fable' of the Rake (Griffiths, 1982). But, at this relatively unproductive stage of his career and in his somewhat despondent frame of mind he may well have identified himself with the mad musician. He may also have been reminded of the psychological problems of some of the distinguished composers he knew (the mad genius hypothesis). Post (1994) in his study of creativity and psychopathology in 291 world-famous men used a four-point scale for psychopathology (none, mild, marked, severe) and rated the psychopathology of Stravinsky and RimnskyKorsakov, his teacher, as "marked". His collaborator, Robert Craft (1992), describes Stravinsky as "extremely anal, exhibitionistic, narcissistic, hypochondriacal, compulsive . . . deeply superstitious . . . quarrelsome and vindictive." The psychopathology of Satie, Gide and de Falla, all of whom Stravinsky knew well, was rated by Post as "severe". Nijinsky, another friend of Stravinsky's, spent several years in psychiatric institutions and diagnosed as suffering from schizophrenia by Eugen Bleuler.

Stravinsky's working method involved using diverse sources, including fables, myths, folk tales, pagan rituals, Greek tragedy and fairy stories, and recasting them in a new form in order to pack in as many resonances and layers of meaning as possible. There are musical allusions in this score to operas by several other composers, especially Mozart. In this sense the Rake's Progress is an opera about opera, a self-consciously autoscopic enterprise. This cultural-magpie approach, a method by no means unique to Stravinsky, is employed effectively in the Rake's Progress, and especially so in the final Bedlam scene. If Auden is right and the mad musician in this scene was in fact the spark which fired Stravinsky's desire to write the opera, yet another possible dimension is added: that of Stravinsky's hypochondriacal fears for his own sanity.

Stravinsky's high hopes in the Rake's Progress were disappointed. The critics, by and large, found it ingenious, but conventional. Stravinsky was depressed again, but this time not for long. A few months later he began to study the serial composers, Webern and Schoenberg, and was able, with their help, to find a new way to express his musical genius.

\section{References}

AUDEN, W. H. (1968) Secondary Worlds. London: Faber \& Faber.

Carpenter, H. (1981) W. H. Auden. A Biography. London: George Allen \& Unwin.

CRAFT, R. (1992) Strauinsky: glimpses of a life. London: Lime Tree.

GRIFFTHS, P. (1982) Igor Stravinsky. The Rake's Progress. Cambridge: Cambridge University Press.

Pope, A. (1943) The Poems of Alexander People, vol. 5, The Dunciad. London: Methuen.

Post, F. (1994) Creativity and psychopathology. A study of 291 world-famous men. British Journal of Psychiatry. 165, 22-34.

STRAVINSKY, I. \& CRAFT, R. (1960) Memories and Commentaries. London: Faber \& Faber.

- (1982) Selected Correspondence, edited with commentaries by Craft, R. London: Faber \& Faber.

P. Crichton, Senior Registrar, The Maudsley Hospital, London SE5 8AZ 